\title{
Why and How EFL Students Learn Vocabulary in Parliamentary Debate Class
}

\author{
Eunice M. Aclan (Corresponding author) \\ University Research Center and Center for Graduate Studies \\ Adventist University of the Philippines \\ 4118 Silang,Cavite, Philippines. Mail: P.O. Box 1772 and P.O. Box 18341099 Manila Philippines \\ E-mail: nice_aclan@yahoo.com \\ Noor Hashima Abdul Aziz \\ School of Education and Modern Languages \\ Universiti Utara Malaysia \\ 06010 UUM Sintok Kedah Darul Aman Malaysia \\ E-mail: noor934@uum.edu.my
}

Doi:10.7575/aiac.alls.v.6n.1p.102

Received: 21/09/2014

URL: http://dx.doi.org/10.7575/aiac.alls.v.6n.1p.102

Accepted: 27/11/2014

\begin{abstract}
Vocabulary, the backbone of any language including English, is foundational for listening, speaking, reading and writing. These four macro-skills are necessary not only in gaining knowledge as English is the language to access major information sources particularly the World Wide Web but also in the demanding globalized workplace. Vocabulary is seen to be learned better when it is contextualized thus language teachers should design communicative activities such as debate. However, debate, being more known as a competitive rather than a classroom activity worldwide, has not been explored yet for its potential to develop vocabulary among EFL/ESL students although it has been identified for its power in developing communication skills in general as well as critical thinking and other soft skills. Thus, this qualitative study was conducted to explore why and how EFL students learn vocabulary in classroom debate. The data were gathered through end-of-course evaluation and focus group interview with seven participants from the Middle East, African and ASEAN countries. The findings show that students learned vocabulary due to debate's interactive nature requiring contextualized and meaningful language use from preparation to actual debate. EFL students described how they learned vocabulary through debate which has implications for SLA and language teaching.
\end{abstract}

Keywords: Noticing hypothesis, Comprehensible input, Incomprehensible input, Vocabulary building strategies

\section{Introduction}

\subsection{Background of the Problem}

In the $21^{\text {st }}$ century globalized economy, English plays a major role being the international language and the lingua franca of the ASEAN region. Since ASEAN is a block with highly diversified culture with over 1,000 languages being spoken in the region, the association of 10 Southeast Asian countries declared in Article 34 that "The working language of ASEAN shall be English" (The ASEAN Charter, 2008 p. 29). "This contrasts strikingly with the European Union (EU), where there are twenty three official languages," according to Kirkpatrick (2010, p. 3). However, EU being richer than ASEAN invests on hiring linguists, interpreters and translators. European Union has a permanent staff of 1,750 linguists and 600 support staff and it is one of the world's largest translation services with 600 full-time and 3,000 freelance interpreters (European Commission). This shows how important a unifying language is globally for a common understanding. Thus, even the foreign students from the Middle East, Africa and ASEAN countries, the participants of this study, said they chose Malaysia for their higher education in order to learn English as one of their main reasons. As they are Engineering and International Business students, they believe that English is very important in their career someday as it is the language of science, technology and global business as shown in the needs analysis conducted with them prior to their taking of the pre-university English courses. They indicated that although some of them can converse in English, their weakness is on academic English including listening, speaking, reading and writing due to lack of vocabulary.

Vocabulary means "learning meanings of new words" or "words that a reader recognizes in print" (Beck, McKeown, \& Kucan, 2008, p. 1). Vocabulary is necessary not only in reading and writing but also in listening and speaking. Lack of vocabulary affects fluency in speaking and speed and process of reading, writing and listening. For example, speakers and writers with limited vocabulary may pause a lot to think of the right or appropriate word to say next; readers may stop to find the meaning of difficult words in the dictionary; listeners may not completely comprehend what they hear due to unfamiliar vocabulary. Lexicon or vocabulary is considered by Gass and Selinker (2001) as the most important language component for learners and they said that large corpora of errors constantly show that lexical errors are the most common among second language learners. For Brown (2001), "Words are basic building blocks of language; in 
fact, survival level communication can take place quite intelligibly when people simply string words together - without applying any grammatical rules at all! So, if we're interested in being communicative, words are among the first priorities" (p. 377). Furthermore, Wilkins (1987) stated that, "Without grammar very little can be conveyed, without vocabulary nothing can be conveyed" (p.135). Indeed, vocabulary is very basic in all the four macro-skills.

Sternberg (1987) said that it is common knowledge that people learn most of their vocabulary by reading. Furthermore, Krashen (1993) stated that"Reading is good for you. Research supports a stronger conclusion, however. Reading is the only way, the only way we become good readers, develop a good writing style, an adequate vocabulary, advanced grammar, and the only way we become good spellers" (p. 23). Krashen proposed the use of contextualized comprehensible inputs for second or foreign language learning. Like Krashen (1993), Hadley (2000) recommends contextualized language learning and teaching. Learning vocabulary in context is also supported by Brown (2001). Brown said that, "Rather than viewing vocabulary items as a long and boring list of words to be defined and memorized, lexical forms are seen in their central role in contextualized, meaningful language" (p. 377. It is the responsibility of language teachers to make students of all proficiency levels including the low and advanced ones level up in their proficiency by expanding or maximizing their vocabulary repertoire. Debate is one way of using the target language contextually particularly vocabulary learning. Gu (2003) suggests that vocabulary learning strategies should include not only knowing a word but also using it and in his later study (2010), he pointed out that literature is scarce in terms of productive and active vocabulary learning strategies. Moreover, there have been no studies on how debate can develop the vocabulary of EFL/ESL students thus this qualitative study is necessary.

\subsection{Statement of the Problem}

Language learning plateau happens when students lack the motivation in further developing the basic language skills that they possess brought about by boring language classes (Richards, 2008). Thus, it is a challenge for language teachers to design fun, motivating and interesting language activities that will make the learners advance their proficiency particularly vocabulary as there are approximately a million words in English which cannot be all taught in the language classroom. One way of facing this challenge is by explicitly designing language activities that will expand the EFL learners' vocabulary repertoire so that they will improve in their listening, speaking, reading and writing which all require understanding and appropriate use of lexical items. Even in the United States, many students struggle with reading due to limited vocabularies as one of the main reasons (Fusaro, 2009). Fusaro explained that, "Limited vocabulary, low reading ability, and low investment of time in reading often go hand in hand, since students usually learn more sophisticated words through reading, rather than from informal sources" (para. 1). We cannot rely on requiring our students to make a habit to list and define a number of words without having them use such words actively in communicative functions. By designing a language activity that will necessitate vocabulary learning in context, learners can expand their vocabulary to improve their English proficiency for better learning in a university that uses English as a medium of instruction and for effective communication along with other soft skills developed by debating such as critical thinking they need in their future job.

There have been a number of studies conducted on the benefits of debate (Akerman \& Neale, 2011; Bellon, 2000; Goodwin, 2003; Inoue \& Nakano, 2004; Kennedy, 2009; Scott, 2008; Yang \& Rusli, 2012) but most of these have dealt with critical thinking and communication skills in general and no one has focused on vocabulary learning. These studies were conducted mostly in English speaking countries, with only Yang and Rusli's study done in Singapore in ESL context and Inoue and Nakano in Japan, an EFL context but none of these touched on vocabulary learning. Thus, this knowledge gap was filled in this study by showing how and why EFL/ESL students develop vocabulary through classroom parliamentary debate.

\section{3 Purpose of the Study}

Debate is defined by Freeley and Steinberg (2013) "as the process of inquiry and advocacy, a way of arriving at a reasoned judgment on a proposition" (p. 6). For Snider and Schnurer (2006), "debate is an equitably structured communication event about some topic of interest, with opposing advocates alternating before a decision-making body" (p. 6). As an ancient Greek teaching pedagogy, it is more widely used worldwide as a competitive activity than as a teaching tool (Akerman \& Neale, 2011; Goodwin, 2003; Kennedy, 2009; Scott, 2008). Debate is known in the literature as an activity that can improve critical thinking skills, communication skills, research skills, teamwork and confidence (Goodwin, 2003; Hall, 2011; Scott, 2008; Yang \& Rusli, 2012). Akerman and Neale (2011) and Bellon (2000) said that debate can improve English if it is not the learners' first language. However, there are no studies on debate dealing with why and how it can develop English as a Foreign Language (EFL) or English as a Second Language (ESL) students' vocabulary. Gass and Selinker (2001) pointed out that the major task of second language lexical researcher is to discover how students learn vocabulary and why they learn the way they do. Thus, the purpose of this qualitative study is to show why and how EFL students from Middle East, African and ASEAN countries purposively chosen learn vocabulary by debating. Specifically, this study answered two research questions: (1) Why is vocabulary learning necessary in debate from the perspective of the participants? (2) How do EFL students learn vocabulary by debating?

\section{Method}

\subsection{Research Design}

This study used qualitative case study design. Qualitative research involves the use of a wide array of empirical materials such as interviews, observations and document analysis to describe the subject matter at hand to consequently lead to an accurate interpretation and better understanding (Denzin and Lincoln, 2005, Patton, 2002). According to Baxter and Jack (2008), qualitative case study is "an approach to research that facilitates exploration of a phenomenon within its context using a variety of data sources" (p. 544). More importantly, to answer "how" and "why" questions as the case of this study, qualitative inquiry offers a great advantage (Baxter \& Jack, 2008; Guest, Namey \& Mitchell, 
2013), i.e., to provide understanding, meaning, context and process (Maxwell, 2005). As the focus of qualitative case study is on "holistic description and explanation" (Merriam, 1998, p. 29), this study reported comprehensive findings and interpretations that will provide a deep understanding of why and how EFL students learn vocabulary by debating and why they learn the way they do.

2.2 Participants of the Study

The participants of this study were seven EFL students who debated at least six times and attended at least 70 percent of the 16-week classes as a requirement in their two Listening and Speaking (debate) classes in a five month intensive English course (IEC). The IEC composed of Reading, Writing, Listening and Speaking. IEC students were placed in their respective levels based on their English Placement Test (EPT) results using paper-based ITP-TOEFL. The following ITP-TOEFL scale of English language proficiency to categorize the participants of this study was used for the purpose of increasing the transferability of the results of this study as it establishes the need for students to gain a great deal of vocabulary in order to improve their overall English proficiency.

Table 1. TOEFL score scale (Source: ETS, 2014)

\begin{tabular}{ll}
\hline TOEFL Score & English Proficiency Level According to Common European Framework \\
of Reference (CEFR)
\end{tabular}

Most of the IEC students in the locale of this study came from countries where English is rarely used or not used at all except in the English classrooms such as in the Middle East where Arabic is their official language. Two of the participants were from Syria, two from Yemen, one from Chad, one from Somalia and one from Thailand. Their average entrance English proficiency as shown in their EPT, is relatively low. The intake from which the participants of this study were selected (March - September 2013) had an average score of 363 interpreted as basic user of English. Universities in the US accept a TOEFL score of at least 500 or its equivalent while the debate students chosen as participants in this study ranges from 360-410 with an average score of 387, way below the threshold set in American, British or Australian universities operating in English medium academic endeavors. Table 2 shows the demographic profile of the participants including their TOEFL score.

Table 2. Participants' demographic profile

\begin{tabular}{llllc}
\hline & Participants (Pseudonym) & Country & First Language & TOEFL Score \\
\hline 1 & Mohammed & Somalia & Somali & 387 \\
\hline 2 & Mustafa & Chad & Arabic & 377 \\
\hline 3 & Teerapong & Thailand & Thai & 373 \\
\hline 4 & Khalid & Yemen & Arabic & 410 \\
\hline 5 & Malek & Yemen & Arabic & 360 \\
\hline 6 & Ahmed & Syria & Arabic & 393 \\
\hline 7 & Musa & Syria & Arabic & 407 \\
\hline
\end{tabular}

The participants' TOEFL scores show that they really need opportunities to increase their vocabulary. Besides, in a Needs Analysis administered prior to their debate class, 26 out of $28(93 \%)$ debate students indicated that they needed to improve their vocabulary. Specifically, the Needs Analysis also showed that they needed activities that would make them increase their vocabulary for them to use when they listen, speak, read and write (strongly agree $=82 \%$ ).

\subsection{Sampling Techniques}

The study used purposive sampling as samples were purposefully chosen among 28 debate students from March September 2013 intake of pre-university Intensive English Course. Seven out of 28 students were selected based on the end-of-course evaluation sheet with open-ended questions and on their willingness to be interviewed. Eleven students reported great improvement in their vocabulary through debating but only seven agreed to be interviewed. The other four said that they were going home to their country on the proposed focus group interview session.

2.4 Data Gathering Methods and Procedures

Data for this study were gathered from two sources, i.e., qualitative documents and focus-group-interview (FGI). Creswell $(2012,2013,2014)$ cited qualitative document and FGI as the most commonly used data gathering methods in qualitative studies.

\subsubsection{Document}

Documents can be a valuable source of information in qualitative research (Creswell, 2012). Document analysis is a method commonly used in case studies to give a variety of information sources (Hancock \& Algozzine, 2006). However, they caution that if the researchers decide to utilize documentary evidences, they should be clear why they are appropriate. In the case of this study, feedbacks written by the debate students themselves are gathered from natural setting describing their experiences on the benefits of debating particularly in terms of vocabulary development. Thus, they are appropriate to be used in answering the research questions of this study aside from they served as the basis for 
the recruitment of the participants.

The end-of-course evaluation contained six open-ended questions. The first three questions were the bases of the selection. These questions were: (1) Has this debate class improved your English? If yes, in what aspect and HOW? (2) What did you like most in this debate class? WHY? (3) Would you recommend this class to the next intake or to your friends? Why or why not?

\subsubsection{Focus group interview}

Focus group (FG) was the major tool used to gather data in this study. FG is defined by Krueger (1994) as "a special type of group in terms of purpose, size, composition, and procedures. [It] is typically composed of 7 to 10 participants who are selected because they have certain characteristics in common that relate to the topic of the focus group" (p. 6). For Creswell (2014), four to six interviewees are ideal for a focus group interview to make it more manageable particularly in terms of transcribing the data but for Tracy (2013), FGI is composed of three to 12 participants. The key here is to gather rich and deep data in order to come up with a thick description of the phenomenon studied (Bazeley, 2013; Tracy, 2013). Guest, Namey and Mitchell (2013) suggested six to 12 FG interviewees with eight individuals as minimum. Like Bazeley (2013) and Tracy (2013), Guest, Namey and Mitchell, however, emphasized that, "The main factor to consider in this regard is the breadth-to-depth ratio most suitable for your topic and population" (p. 177). They further gave some important guidelines for adjusting focus group size. They said that researchers can use smaller groups when:

- Participants are highly involved with the topic

- Participants know a lot about the topic

- The topic is complex

- You're looking for detailed narratives (p. 177).

In this study, the seven students who indicated that they improved in their vocabulary in the end-of-course evaluation agreed to be interviewed were selected. As these debate students are always highly involved in any topic they debate on and know a lot about the complex topic of this study particularly on how debate can increase vocabulary, they were expected to give detailed information from their debating experience specifically on vocabulary development.

In conducting the FGI, the seven debate students were asked of their common available time for the focus group interview. Prior to the semi-structured interview, they were explained that the interview would take over an hour. They were also asked to answer in full details as much as possible and that they would be asked follow up or probing questions so that rich and meaningful data would provide a deep understanding on how debate can increase vocabulary among EFL students. The interview was audio-recorded for high fidelity (Rudestam \& Newton, 2007), for audit trail and for reliable transcription.

\subsection{Data Analysis}

Following Miles, Huberman and Saldaña's (2014) interactive model of data analysis, three streams of analytic process were used in this study: data condensation, data display and drawing/verifying conclusions. Data condensation, according to Miles, Huberman and Saldaña's (2014), "refers to the process of selecting, focusing, simplifying, abstracting, and/or transforming the data that appear in the full corpus (body) of written up field notes, interview transcripts, documents, and other empirical materials. By condensing, we're making data stronger" (p.12). Further episodes of data condensation such as writing summaries, coding, theme and category development and writing analytic memos take place simultaneously during data collection and analysis and continue when the fieldwork is over (Miles, Huberman and Saldaña). Then the condensed data are displayed to allow conclusion drawing. Thus, in this study, the data from both the end-of-course evaluation and the FGI were condensed, i.e., selected, focused and transformed. The condensed data were summarized and coded based on the research questions then the themes were displayed with the supporting verbatim excerpts from the participants to provide context and deep understanding of how and why EFL students learn vocabulary by debating.

\subsection{Ensuring Rigor and Trustworthiness}

To provide check and balances on standards of scientific qualitative inquiry, rigorous data gathering and analytic methods were observed in conducting this study. Guba's (1981, as cited in Krefting, 1991; Guba \& Lincoln, 1994) trustworthiness model deals with the four issues on qualitative research, namely, credibility, transferability, dependability and confirmability. Guba proposed this model to evaluate the rigor and trustworthiness of qualitative methods and findings as readers construct meaning when they relate a study to their own context. Padgett (1998, cited in Padget, 2004) identified six strategies to enhance rigor and trustworthiness in qualitative studies: triangulation, negative case analysis, prolonged engagement, member check, auditing and peer-debriefing and support (PDS) group. To ensure credibility, the key strategy, in this study, four strategies, i.e. triangulation, peer-debriefing, member check and appropriate interpretation (Krefting, 1991) were used. Interpretation means "the researcher steps back and forms some larger meaning about the phenomenon based on personal views, comparisons with past studies, or both" (Creswell (2012, p. 257). Creswell further explained that that qualitative research is interpretive thus the researcher should make sense of the study's findings. For Boeije (2010), findings are the "outcomes of the researcher's analytical activities (not the activities themselves) and consist of data and everything the researcher makes out of them, whether descriptions, theoretical models or explanations" (p. 196). In this study, Creswell's and Boeije's definition of interpretation were put together thus the data were interpreted in the light of previous studies, theories and our personal views on the topic. Creswell (2012) listed three ways to validate the accuracy of qualitative research findings, i.e., triangulation, member check and auditing. These three validation strategies on the accuracy of findings were used in this study to ensure rigor and trustworthiness. Data triangulation, i.e., interview and document, was employed in this study. 


\subsection{Ethical Considerations: Confidentiality and Informed Consent}

The participants in this study were on voluntary basis and were asked to sign a written informed consent letter. The focus groups as well as the individual interviewees decided on the schedule when they were free and convenient to be interviewed. They were briefed of the purpose and nature of the study and were assured that there would be no harms or risks in participating in this research. They were also informed that confidentiality and anonymity would be strictly observed as pseudonym would be used instead of their name to protect their identity.

\section{Findings and Discussion}

This section presents the findings of the study with participants' excerpts in verbatim words to answer the research questions. Findings are interpreted and discussed in the light of language learning theories and previous studies.

\subsection{The Necessity of Vocabulary Learning in Debate}

To answer Research Question 1, "Why is vocabulary learning necessary in debate from the perspective of the participants?", data from both the end-of-course evaluation sheet and focus group interview were analyzed. In the endof-course evaluation, Khalid from Yemen, emphasized the nature of debate that necessitates the learning of vocabulary. Khalid said:

In debate, I developed my confidence in speaking very much. I become confident when I know the right words to use when I debate and it's in this class that learning a lot of new vocabulary is a must because we can't debate well if we don't know how to say our point clearly.

For Khalid, saying a point clearly involves use of right words and he implies that by debating, one can learn vocabulary. When Khalid was asked to explain which part of the debate requires learning vocabulary, he answered, "When we prepare for the debate, we research a lot and there's a lot of new words we see when we read about the topic. We need to learn these words because we have to use them during the debate." It is the interactive nature of debate that sets the motivation of students to learn vocabulary even without teacher's instruction. In the FGI, Musa from Syria shared similar experience with Khalid in terms of why it is necessary to learn vocabulary in debate.

I like debate very much because I develop my English a lot. When I debate, I must do research about the motion or topic given to us by our teacher because I can't debate if I don't know about the topic because the topics are new to me. And I write the points I must say especially the new words, yes a lot of new words I never met and used before so I need to remember them, I write them so that I can use them later when I debate. Using the new words when I debate will make me feel like I improved a lot in my English.

It is evident from both Khalid and Musa that the nature of debate necessitates learning of new words. Ellis (2003) states that in task-based language teaching, the teacher should provide an activity that will let the learners develop their language through tasks that make the students solve problems and use the target language. Task is defined by Skehan (cited in Brown, 2001) as "an activity in which meaning is primary; there is some communication problem to solve; there is some sort of relationship comparable to real-world activities; task completion has some priority; and the assessment of the task is in terms of the outcome" (p. 50). As debate students concern on the way they communicate their points to be clearly understood, they therefore consider learning vocabulary as imperative. Vocabulary learning is embedded in the task itself particularly during the pre-debate stage when students are given the time to prepare their speech with their arguments, evidences and possible rebuttals by researching or reading. It is also their English proficiency level that pushes them to learn the vocabulary as shown in the Needs Analysis done prior to the debate class in which they indicated that they want activities that would make them learn vocabulary so that they can function better in speaking, listening, reading and writing. Indeed, debate has satisfied the students' desire to improve their communication skills by increasing their vocabulary so that they can say their point the way they wished to be clearly understood.

Having sufficient vocabulary repertoire also improves fluency like what students observed when they debate. For instance, Ahmed said in the FGI that:

In debate, I need to learn a lot of new words and really memorize them so that I will use them when we debate because if you don't know the right words to say, you will stop or pause a moment to think of the correct word to say. It's researching or reading a lot before the debate that we can learn many, many new words. And these words are used in sentences so we can understand them better and use them in the debate later.

Reading, indeed, is a very good way to develop vocabulary as learners will be able to see how words are spelled and used in a context that they can review anytime which cannot be possibly done in listening. It is by reading that vocabulary can be best learned, according to Sternberg (1987) and Krashen (1993) and this is described by the participants in this study how it can be done. It is the nature of debate itself that makes the students learn new words during the preparation time because they see the necessity of using what they learn later in the actual debate. Although the preparation stage or the pre-debate sets the students' noticing of the new or unfamiliar words, it is the actual debate where the students use the words they newly learned communicatively. Using debate in an EFL classroom espouses the strong version of Communicative Language Teaching (CLT), i.e., letting the EFL/ESL students use English to learn English in a communicative way for them to develop their communication skills (Howatt as cited in Richards \& Rodgers, 2001). By reading in English, learners pick up new English words and remember them for their actual use in the debate. This is using English to learn English as contrary to translation or teachers teaching English such as grammar, in their first language.

Syrian student, Ahmed, also said in the end-of-course evaluation that one of the best things he gained from debating is learning a lot of new words. Ahmed said, "In this class, debating improved me because when I search about the motion I meet a lot of vocabulary I never learned before."

The participants of this study imply that input is necessary in language learning and the role of teacher is vital in 
designing an activity that will expose students to inputs that contain language items particularly vocabulary unfamiliar to students. It they are presented with too easy lessons without anything new to learn, they might not be interested in learning and they will plateau in their proficiency (Richards, 2008). Indeed, in debate, attention to form, particularly vocabulary is evident as described by the participants. In the study of Williams (cited in Gass \& Selinker, 2001), she found that, "when there is learner-generated attention to form, the attention is generally given to words rather than to other linguistic features" (p. 321). Thus, it is important that students be given enough language input. According to Krashen (1987), input is the most important component of language acquisition and students should be presented inputs slightly more advanced than their current level.

Debate adheres to the theory of learning that "people learn a second language more successfully when they use the language as a means of acquiring information, rather than as an end in itself' (Richards \& Rodgers, 2001, p. 209). This goes with the principle that successful language learning takes place when students are presented with the target language material in a contextualized and meaningful way (Hadley, 2001; Richards \& Rodgers, 2001). The participants of this study described the necessity of learning vocabulary in context which they also use in context in actual debate. In fact, Brown (2001) said, "Rather than viewing vocabulary items as a long and boring list of words to be defined and memorized, lexical forms are seen in their central role in contextualized, meaningful language" (p. 377). In debate, students learn vocabulary in a natural way as required by the activity itself even without teacher's explicit instruction on vocabulary learning. It is the design of the debate as a task-based activity itself having pre-debate stage to allow vocabulary acquisition and actual debate to put into actual use the newly acquired words. Debate, therefore, is a pedagogical activity that serves the communicative needs of second or foreign language learners particularly in terms of vocabulary learning for those who have limited opportunities to use English outside the classroom.

\subsection{How EFL Students Learn Vocabulary by Debating}

To answer Research Question No. 2, "How do EFL students learn vocabulary by debating?", four themes emerged from the data: noticing new words, writing down the new words, translating the new words into the learner's first language, examining the new words in context and using the new words.

\subsubsection{Noticing New Words}

Noticing or paying attention to new words emerged as the common theme among all the participants of this study. When asked to elaborate how debate can increase vocabulary, Khalid answered, "When we search about the motion, I can meet a lot of new vocabulary. I pay attention to the new words I meet when I read because I want to really learn new words every day." This shows that the autonomy provided in the debate class to the learners has yielded implicit learning. Ellis (2012) pointed out that when pre-emptive focus on form is initiated by learners themselves, they are provided the opportunity to control the discourse that may enhance the attention they need to pay in order to learn new forms. The Noticing Hypothesis Schmidt developed in 1990 states that input does not become intake for language acquisition unless it is consciously registered, i.e., noticed (Schmidt, 2010). Schmidt argued that attention, a component of noticing hypothesis, is essential to learning; i.e., learning is not possible without attention (Gass \& Selinker, 2001).

Mohammed from Somalia also said in the end-of-course evaluation that, "I learned vocabulary, about 200 new words in a month and I learned to use them when I debate. I'm so happy that my friends who debated with me understand what I'm saying." When asked how he learned new words by debating during the focus group interview, Mohammed answered:

I really look for new words when I do research during preparation for our debate. I copy the new words, and write it [them] in my notes to prepare my speech. Then, I practice to say the new words and use them when I deliver my speech.

While Khalid meet new words and pay attention to them when reading for the assigned motion or topic for debate, Mohammed intentionally look for new words. Nevertheless, both show that noticing or attention is important in learning new words. Khalid described how he learned new words in debate by paying attention to the new or unfamiliar words coupled by his personal desire to learn new words on a daily basis. Similarly, Mohammed showed his motivation to intentionally look for new vocabulary. Locke and Latham's (cited in Dornyei, 2001) goal-setting theory asserts that human behavior is caused by purpose thus goals must be set and realized by choice so that action will take place.

Similar to Khalid's and Mohammed's noticing of new words, Teerapong, a Thai student, commented in the end-ofcourse evaluation that, "When I read about the topic, I find a lot of new words and I feel great I can use them when we debate." When asked to explain how he learned the words during the preparation for debate, Teerapong answered:

When we have discussion in our team to prepare for the debate, I notice that my team-mates also use the new words that I learn for the first time. So, when I read and hear these new words, they become familiar to me and make me remember them more.

It is interesting to note that Teerapong does not only learn new words from reading but also from noticing them when his team-mates use such unfamiliar words. Ahmed, on the other hand, suggested another strategy of learning a new vocabulary during the FGI. He said that:

We must be keen enough to identify the new words or the words we don't understand and we learn that they are important because they are repeated many times when we read about the motions. It's also good to find the synonyms of words in what we read, analyse how they are used and then we use them later in the debate.

While Teerapong said that noticing by listening to how other debaters use the new words he has learned, Ahmed used another noticing strategy, i.e., finding synonyms in the text and analysing how they are used in context to prepare for actual use during the debate. It is, therefore, through noticing that learning of new words takes place. As shown in the excerpts from the participants of this study presented above, noticing is very important in the students learning of new words. Schmidt's (1990) noticing hypothesis states that learners notice language aspects in the input that become intake. 
Schmidt considers noticing as a very important condition in second language acquisition (SLA). Ellis (1997), clarifying Schmidt's hypothesis based on current theories of second language acquisition, posited that there are two major stages involved in the input processing to become knowledge. The first stage, where the input becomes intake, involves noticing language aspects, absorbing such features into the learners' short-term memory and analyzing them to produce output. The second stage is when intake is registered in the long-term memory, i.e., when it is absorbed into the learner's interlanguage system. Ahmed and Mohammed manifested these two stages of input processing. For example, both first noticed the new words and Ahmed even analyzed them including their synonyms and how they were used in context. On the second stage, they actually used the newly learned words when they debated showing that the new words have been registered in their long-term memory to become part of their interlanguage by actually using them.

Input is, therefore, very important in language learning. It is then the main role of language teachers to ensure that students receive comprehensible input (Gass and Selinker, 2001). However, Sun (2008) in discussing input processing in SLA, pointed out that incomprehensible input is also necessary for language acquisition to take place. It may sound contradictory to Krashen's comprehensible input represented by his $i+1$ formula, i.e., a bit of language, heard or read, slightly ahead of a learner's current linguistic knowledge. While this slightly ahead condition is not well defined, Sun presented a better alternative of understanding it that might be more helpful in language pedagogy. Sun explained that:

Had everything in the input been completely understood, learners would generally feel no need to attend to forms, and acquisition of missing structures would not occur. In other words, because of the incomprehensibility of the input, learners' attention is drawn to the specific structure. (Sun, 2008, p. 6)

From the perspective presented by the participants of this study, it is indeed the incomprehensible input, i.e., new or unfamiliar words they notice when they read or research during the preparation time for the debate. This supports Richards' (2008) point that learners have to be presented challenging activities that will encourage them to level up from their current language proficiency level. Furthermore, language containing structures learners already know essentially serve no purpose in language acquisition (Gass \& Selinker, 2001), thus the $i+1$ in Krashen's input hypothesis could even be more complex to provide motivation to level up particularly for more fast and advanced learners to avoid learning plateau. Debate is one activity that provides challenge to the students in that they have to solve a problem where the learners collaboratively prepare by researching for the actual debate while they autonomously enhance their vocabulary and eventually their interlanguage by noticing the inputs they independently search and share with their team.

\subsubsection{Writing Down the New Words}

Mustafa, a debate student from Chad, wrote in the end-of-course evaluation that, "the debate class helped me very, very much in improving my listening and speaking because I learn a lot of new words. This is the best English class to make students learn more advanced English words." In the focus group interview, Mustafa explained how he learned new words by debating.

I write the new words in my notes so I will not forget them and will be easier for me to use them during the debate. And even after the debate, I can review the words I write because if I don't use the new words I learn, I easily forget them. That's why I need a note of the new words I learn so I can see them again and again until I know them very well.

Mohammed gave a similar description on how he would ensure that he could review and recall the words he newly acquired by saying:

Writing the new vocabulary I read when I do the research when we prepare for debate is important for me. Why? Because these words are really new to me and they're hard to memorize so I need to use them often. If I write them down, I can always visit them until they become part of my regular vocabulary.

Writing down the noticed words is part of the cognitive process the students strategize for them to remember the new words they have learned. As Mustafa and Mohammed said, jotting down the unfamiliar words help them memorize and recall the words because they can review them at a later time. Students with advanced language proficiency also write down unfamiliar words they encounter when they read during the preparation for debate. In our previous study (Aclan and Abd. Aziz, 2014), Sonya, one of our participants who is a debate trainer and a former debater with advanced language proficiency, said:

In the preparation for the debate, I need to read a lot and reading also not only increase my knowledge or my ideas but I also improve my vocabulary. Because when I read, I get lots of new information and meet new words and I try to remember the new words. I write the new words I learn and try using them during the debate and even after the debate. And this works very well for me to improve my English and my communication skills because I can say exactly what I mean with the right words. (p. 7)

Developing a strong vocabulary is essential for communicating accurately and precisely, according to Chasen and Putnam (2012). These authors advised that it is a good idea to keep a handy notebook or even a section in the phone to record newly learned words which can be revisited at a later time. In the empirical research review by $\mathrm{Gu}$ (2003) on second language vocabulary learning, he found that very few studies have touched on note-taking as a vocabulary development strategy. Not only did he mention the scarcity of previous studies but also the dire need for research on how note-taking can influence vocabulary development. As shown by the participants of this study and even in previous research, keeping a list of newly learned words facilitates the storage of vocabulary from short-term memory to long term memory. Thus, students have to be encouraged to keep a record of their newly learned vocabulary to aid their memory until the new words become part of their interlanguage system. 
3.2.3 Using Dictionaries and Translating the New Vocabulary

Malek from Yemen commented in the end-of-course survey that, "This class is the best in improving my English especially my vocabulary. Now I know a lot of new words which I learned because I want to be good when I debate and also when I write. Using the right words is very, very important when we communicate." When asked how he learned new vocabulary by debating, he said that:

I always have my cellphone with a translator and dictionary. Whenever I see a new word I don't understand, I check my cellphone. This way helps me understand the meaning of the new word. Sometimes, I also use the Google translator from English to Arabic and this helps me see how it is used in the sentence.

Teerapong also gave a similar answer as follows:

My e-dictionary can translate everything and I can also listen to pronunciation of the new words I learn in English. When we prepare for debate, I have to understand the difficult words I read and the easiest way is to use my e-dict. Even in high school, I always used my e-dictionary because I learn new words faster if I translate it [them].

While translators in the Internet abound, students must be cautioned that these are not always accurate. Thus, they should be encouraged to use paper or printed dictionaries particularly if they are still in the lower proficiency level although it is quicker and more convenient to use Internet dictionaries and translators. Khalid, although he was more advanced in terms of language proficiency among the participants, also said he used his mobile phone to translate new and difficult words he encountered when preparing for debate. He explained:

Although we're taught to use context clues to guess the meaning of words we don't understand, it's good to check the translation because it makes me more confident to use the new word correctly. The translator can make my life easier (laugh).

The participants of this study shared how they used a bilingual dictionary to aid them with the meaning of the new words they learn. Although Brown (2001) advised to downplay the role of bilingual dictionaries in the guideline he set for communicative treatment of vocabulary instruction, the participants of this study found the use of translation or bilingual dictionaries helpful in their language learning. There are marked differences of stance in terms of allowing first language (L1) use in the classroom, according to Ellis (2012). For example, Ellis presented the study by Broner in 2001 which showed that children sometimes used their L1 depending on the social relationships such as they use L1 with their fellow learners but not with their teacher. Broner also reported that the use of L1 depends on the activity, whether the learners were on-task or off-task. Broner's findings provide L2 teachers delineation as to when to allow L1 use in the language classroom. In this study, the participants used bilingual dictionary during off-task, i.e., during the preparation time given for the actual debate as they described to facilitate them for a better understanding of the unfamiliar words but they definitely used English all throughout the actual debate.

Allowing the students to use L1 during the preparation time if they feel that it makes them more confident when they think they understand the words better or they construct their sentences better by helping them analyze the words with the aid of their L1 could be beneficial. Although it is beyond the scope of this study, students should be trained to learn vocabulary in context as Brown (2001) suggested. The purpose of this study is to describe how debate students learn vocabulary by classroom debate and the participants revealed that using a bilingual dictionary to translate the new English words to their first language facilitates their vocabulary learning.

Khalid implies that he combines guessing of meanings from the context clues and the use of dictionary and translators. He also said that using a monolingual dictionary aids in learning word forms and correct usage. He said:

The English to English dictionary is more helpful to me to see if it's a noun or adjective and I can see the different forms of the word so that I can use it in the sentence correctly especially that my dictionary gives examples how words are used.

According to Harmer (1993), vocabulary learning requires the ability to know the definition of the word, its formation and correct grammatical usage. The use of monolingual dictionary is more appropriate in knowing word forms and usage while the bilingual dictionary is considered by the participants of the study more helpful in terms of understanding the meaning of the word. In the study by Chen (2012), she found that the use of bilingual dictionary among undergraduate English majors in Chinese universitites can effectively aid vocabulary comprehension and improves incidental vocabulary acquisition as in the case of the participants of this study. This finding made Chen conclude that dictionary use is a more effective vocabulary learning strategy than contextual guessing. However, from the finding of this study, it is good to combine the use of dictionary and contextual guessing as well as monolingual and bilingual dictionaries. It is an issue if the texts read by students do not contain enough context clues to facilitate understanding of unfamiliar words, thus the use of dictionary is necessary. As to whether monolingual or bilingual dictionaries should be used, it depends on the level and purpose of the students. If it is about better understanding of the meaning of the word, bilingual dictionary serves better purpose particularly for lower proficiency students who are still struggling in understanding the definition provided by the dictionary that are sometimes even harder to understand than the word defined. Certainly, monolingual dictionary is the only option for word forms particularly if it offers ample examples of correct usage in various forms.

3.3.4 Using the New Words in Context through Interaction

Another strategy the participants of this study identified to learn a new word is to use it in context through interaction during the actual debate. Mustafa said in the FGI:

I can't believe I learned a lot of new vocabulary, very hard words in English, only in debate. It's in this subject that I enjoy the pressure like someone is pushing me to do my best and that makes me use new words I never used before when I debate. I want to show that my English really improved because I use the right words to 
say my points when I debate with my opponents.

From Mustafa's comments, he implied that it is the interactive nature of debate that pushed him to use new words to express his points accurately and contextually through actual debate. Indeed, to communicate clearly and effectively, whether in the first or second language, right choice of words is necessary. Mustafa also shows his motivation that his English has improved when he uses the appropriate words to debate, an aspect of learner autonomy. In selfdetermination theory, learner autonomy and challenge in L2 learning increase motivation (Dornyei, 2001). As Mustafa described above, he enjoyed the pressure in the debate itself including learning of difficult words he never used before and he was determined to show that he improved his English by saying his points using accurate words. He considered the complexity and the difficulty of the activity including use of newly learned words to communicate interactively in debate challenging.

Mohammed, like Mustafa, used the new words he learned in context, i.e. saying his point during the debate. He said:

Like Mustafa, I use new words many, many times especially important words to say my point during the debate. And when I listen to my opponents, they also use the words I say and I feel very happy that we understand each other. Actually, most of us learn these new words together because all of us, I think, debate for the first time and use English also this way, I mean, in long speech and in academic topics that use these new words because in our country we don't use English much. Debate is really a good way to practice our English especially learning new words because we're given time to prepare before the debate so we can practice using the words before we finally use them during the debate.

Mohammed brought a new point in using new words in context, i.e., repetition. Repetition is one of the three basic learning principles by Thorndike (1999); the other two are readiness and effect, related to motivation. Students learn best and register in their long-term memory information they have learned when they are given review or reinforcement and meaningful practice. This is particularly applicable to learning of unfamiliar words by EFL students. Mohammed also mentioned that listening to his opponents use the same words he has learned reinforced his learning. He also highlighted the preparation time provided not only to spot new words to use but to practice them in context before students finally use them in the actual debate. Thus, debate is a pedagogical tool that can promote vocabulary learning as students are given time to prepare to develop their confidence before they will be asked to perform the main task, i.e., the actual debate. The discussions during the pre-debate stage itself sets the confidence of the students as these smallgroup discussions, i.e., by team of three members using the All-Asians Parliamentary Debate, allow rehearsal not only in terms of using the vocabulary they have newly learned but also the ideas or arguments they have prepared. This shows that words and ideas are inseparable thus contextualization is embedded in debate as an activity itself.

In the same vein on contextualization, Malek said during the FGI that:

The more we can see the same words used in sentences in what we read, the better we learn the new words.

And the more we practice saying them when we are preparing for our debate makes us more confident in using the new words we learn. Then the more we use the new words we learn, the better we remember them.

Malek pointed out a very important pedagogical aspect of debate in terms of learning new words, i.e., like what Mohammed mentioned, is the repetition of unfamiliar words in sentences or in context. However, for Malek, it is not only the repetition by saying the words over and over and from what he hears from his fellow debaters but the repeated use in sentences in the text itself. This has something to do with the initial noticing stage of the unfamiliar words when the debaters are still gathering information by reading or researching. If we teach writing, we emphasize the idea of repetition of key terms to achieve coherence and debaters are also aware that key terms are repeated over and over. Malek noticed this strategy of repetition in the texts he read to prepare for the debate. He also reinforced the idea of repetition in terms of using the new words in the actual debate so that they can be registered in the long-term memory and be part of the learner's interlanguage system. Indeed, the interaction in the debate classroom develops vocabulary and consequently English communication in general as students are given the chance to fill in information and opinion gaps through the debate, which is mainly a problem-solving task. Pica and Doughty's (cited in Ellis, 2012) findings showed that small group in language classrooms yielded more negotiation tasks compared to teacher-centered lessons when the activity was an information type. It is through the interaction that students use the new words they learn in a contextualized and meaningful way. Musa also supported this meaningful contextualization of vocabulary use in debate when he said:

It's so important to understand how the word is used in the sentence. I hate my teacher before who let us write 50 English words every week, yes every week, and we give the meaning of the words and use in the sentence. This way is not effective for me. It's different in debate because I enjoy learning the new words even if it's [they're] hard because I need to use them when we debate. I need to make my opponents and my adjudicator understand me by using the right vocabulary.

Musa pointed out the importance of actually using the words he learned. In the study of Fan (cited in Gu, 2010), she explicitly tried to discover strategies for active vocabulary but none of the seven strategy items in her Vocabulary Learning Strategy (VLS) questionnaire significantly correlated to the test scores of active vocabulary test aimed at active vocabulary use. In this study, the finding shows that the participants who are EFL learners with basic user - way stage English proficiency level deliberately learn new words in order to actively use them in actual performance, i.e. by debating. Ahmed even said that it is in debate that he can really practice using new words he has learned in context and actively use them because he can freely repeat using them during the brainstorming and throughout his speech and he can also listen to other debaters using them until they become familiar. Gu (2010) recommended that, "Future research can examine how the other forms of contextual encoding (i.e., remembering new words with context, and using a new word in context) relate to other strategies and to other learning results. This reported study has presented how noticing 
of new words, finding their meaning in the dictionary or by context clues or both, examining their forms and noting them down for later retrieval to aid memory and using them in context during discussion and in actual debate.

The strategies in learning vocabulary through debate used by the participants in this study can be summarized with the following table as conceptualized by Gu and Johnson (1996, cited by Ghazal, 2007).

Table 3. Vocabulary Learning Strategies

\begin{tabular}{|c|c|c|c|}
\hline Metacognitive & Cognitive & Memory & Activation \\
\hline$* \quad$ Selective & * Guessing: & Rehearsal: & * Using new words \\
\hline $\begin{array}{l}\text { Attention: } \\
\text { Identifying essential } \\
\text { words for }\end{array}$ & $\begin{array}{l}\text { Activating } \\
\text { background } \\
\text { knowledge, using }\end{array}$ & $\begin{array}{l}\text { Word lists, } \\
\text { repetition, etc. }\end{array}$ & in different contexts \\
\hline comprehension & linguistic items & * Encoding: & \\
\hline $\begin{array}{l}\text { * Self-initiation: } \\
\text { Using a variety of }\end{array}$ & * Use of dictionaries & $\begin{array}{l}\text { Association } \\
\text { (imagery, visual, } \\
\text { auditory, etc.) }\end{array}$ & \\
\hline $\begin{array}{l}\text { means to make the } \\
\text { meaning of words } \\
\text { clear }\end{array}$ & * Note-taking & & \\
\hline
\end{tabular}

The participants in this study used selective attention in identifying unfamiliar words and they self-initiated various means not only to understand the meaning of such words but also to put them into actual use through the debates and beyond the classroom. They use dictionaries for meaning and form and note down the words to aid their memory until they can be stored in the long term memory for activation for actual use.

Contrary to rote learning of vocabulary by what Brown (2001) mentioned as just listing of words devoid of context, Musa appreciated the way he learned vocabulary by debating. In fact, he found vocabulary learning by debating enjoyable as he saw the need for him to use them to make the debate audience understand him. He revealed his disfavour with just listing of words required of him every week. According to Gass and Selinker (2001), the primary evidence of second language use, comes from production, i.e., the actual use of language. Production is realized through meaningful interaction. Parliamentary debates are judged with three criteria, namely, matter, method and manner that includes effective and accurate language use thus, appropriate use of vocabulary is necessary.

In All-Asians Parliamentary Debate, memorization is not possible as there is a need for the speaker to interact with his/her fellow debaters through the Point of Information in which the speaker is required to engage with. Thus, debate is an interactive pedagogical activity that requires production of language in a meaningful way making the learning of vocabulary contextualized both during the preparation, mainly from reading and small group discussions and during the actual debate and even during the post-debate stage in which the newly learned words are used in authentic way. Indeed, parliamentary debate is a good platform to practice English.

Although there have been no studies directly relating debate to vocabulary learning except for general reading, the findings of Inoue and Nakano (2004) in their study with EFL students in Japan using British Parliamentary (BP) Debate showed that debate can develop English communication skills. However, Inoue and Nakano's study utilized competitive debate while this study used classroom debate. Also Akerman and Neale (2011) identified improved English communication skills when it is not the students' first language. Nevertheless, the participants of this study reported that they developed their English communication skills in general as they increased their vocabulary that helped them improve their fluency and accuracy in argumentative speaking through debate in the EFL classroom. In the study of Mizumoto and Takeuchi (2008) of 244 university EFL learners in Japan, they found that vocabulary learning strategies had the greatest influence on English proficiency measured by Test of English for International Communication (TOEIC).

\section{Conclusion}

The findings of this study showed that the nature of debate as an interactive activity prompts the students to learn new vocabulary even if they were not instructed to do so. As a task-based student-centered activity, debate requires students to solve a problem autonomously with the teacher as a facilitator, overseer and adjudicator and students assumed that vocabulary learning was embedded in debate itself. The debate structure allows students to prepare for the motion or topic on their own to enable them to learn both content and language that includes appropriate vocabulary use to make the delivery of speech effective. The participants of this study recognized this necessity to be effective in their speech and they also showed their motivation in learning new words that they believed they would use in actual debate. Such recognition and motivation are important factors in second or foreign language learning.

There were four strategies how vocabulary can be learned by debating identified by the participants of this study: noticing unfamiliar words, writing them down, translating the new words into their first language with the aid of a bilingual dictionary and using the new words in context. . These four strategies may not be used in linear order but may be complementary or interacting with each other as vocabulary learning is a process with sub-tasks in which learners differ in their learning strategy preferences. With the lack of existing studies relating debate to vocabulary learning as well as productive and active vocabulary learning strategies, this qualitative study was conducted to show why and how debate can expand the vocabulary of EFL/ESL students. Thus, this study significantly contributes to the fields of SLA and Applied Linguistics particularly on the finding related to the controversial Noticing Hypothesis on how it leads to vocabulary acquisition. It was shown by the participants that noticing incomprehensible inputs, i.e., unfamiliar words 
that caused the communication breakdown when they read, made them focus their attention to such words. The participants manifested two input processing stages supporting Ellis's (1997) interpretation of noticing hypothesis. First, the participants of the study noticed the new words and even analyzed them including their synonyms and how they were used in context. On the second stage, they used the newly learned words in context when they debated showing that the new words have been integrated in their interlanguage system and encoded in their long-term memory.

Another important finding is the use of first language in learning a second language in the classroom. While the use of English to teach English is the norm in the strong version of CLT, the finding of this study showed that learners with basic user stage of proficiency, switched to their first language through the use of bilingual dictionary or translator to facilitate their understanding of the unfamiliar words aside from using context clues. This finding led to a realization that language teachers should be flexible in deciding when first language use should be allowed in the EFL/ESL classroom. In this case, it depends on the activity whether the switching to the first language is on-task or off-task. For example, if restriction is made clear that only English is allowed during the actual debate or the main task, students will follow the same. Although the lecturer did not announce any restrictions, perhaps, the students saw the use of a bilingual dictionary as done not in the productive stage but in the preparatory stage, they resorted to a strategy they deemed facilitative and more efficient for them to use. This temporary explanation needs to be confirmed in the future research. The findings which provided understanding on why and how debate can develop vocabulary among EFL/ESL students also call for a further quantification of vocabulary acquired by the students before and after offering debate using experimental design with a control group.

The findings of this study have implications to language teaching in the EFL/ESL classroom in that, language teachers need to provide language activities that are contextualized, challenging and meaningful for the students where inputs are not too easy for the students so that they will not plateau in their language learning. As input is very important in language learning for them to notice incomprehensible language items such as vocabulary and structure as shown in the findings of this study, it is the responsibility of language teachers to ensure that students receive appropriate inputs so that students will be motivated to further develop their language skills. Finally, it is recommended that debate should be introduced in EFL/ESL language classrooms as it is more widely known as a competitive activity limited to advanced and already developed students if maximum learning of vocabulary and communication in general as well as other soft skills such as critical thinking and teamwork skills is desired.

\section{References}

Aclan , E. , Abd. Aziz, N. (2014). Exploring Parliamentary Debate as a Pedagogical Tool to Develop English Communication Skills in EFL/ESL Classrooms. International Journal of Applied Linguistics \& English Literature, 4(2), 1-16. 10.7575/aiac.ijalel.v.4n.2p.1. Akerman, R. \& Neale, I. (2011). Debating the evidence: An international review of current situation and evidences. Retrieved April 30, 2013 from http://debate.uvm.edu/dcpdf/ESU_Report_debatingtheevidence_FINAL.pdf.

ASEAN Charter (2008). Charter of the Association of Southeast Asian Nations. http://www. aseansec.org/21069.pdf.

Bellon, J. (2000). A research-based justification for debate across the curriculum. Argumentation \& Advocacy, Winter, 36 (3), 161175 .

Baxter, P. \& Jack, S. (2008). Qualitative case study methodology: Study design and implementation for novice researchers. The Qualitative Report, 13 (4), 544-559. Retrieved on June 3, 2013 from http://www.nova.edu/ssss/QR/QR13-4/baxter.pdf.

Bazeley, P. (2013). Qualitative data analysis practical strategies. USA: Sage.

Beck, I. L., McKeown, M. G. \& Kucan, L. (2008). Creating robust vocabulary. New York: Guilford Press.

Boeije, H. (2010). Analysis in qualitative research. USA: Sage.

Brown, H. D. (2001). Teaching by principles: An interactive approach to language pedagogy. USA: Longman.

Chasen, E.A. \& Putnam, R.R. (2012). The Manager's Communication Toolbox. USA: American Society for Training and Development.

Chen, Y. (2012). Dictionary use and vocabulary learning in the context of reading. International Journal of Lexicography 25 (2) $216-$ 247 doi:10.1093/ijl/ecr03. Creswell, J. W. (2012). Educational research: Planning, conducting and evaluating quantitative and qualitative research. USA: Pearson.

Creswell, J. W. (2013). Qualitative inquiry \& research design: Choosing among five approaches. USA: Sage.

Creswell, J.W. (2014). Research design: Qualitative, quantitative, and mixed methods approaches. USA: Sage Publications.

Denzin, N. K. \& Lincoln. S.Y. (2005). Qualitative research. Thousand Oaks, California, USA: Sage Publications.

Dörnyei, Z. (2001). Teaching and researching motivation. Harrow, Essex: Pearson.

Ellis, R. (1997). SLA research and language teaching. Oxford: Oxford University Press.

Ellis, R. (2003). Task-based language learning and teaching. UK: Oxford.

Ellis, R. (2012). Language teaching research \& language pedagogy. USA: Wiley-Blackwell.

European Commission. (2014, last updated Sept. 15). http://ec.europa.eu/languages/policy/language-

policy/official_languages_en.htm

Freeley, A. \& Steinberg, D. (2012). Argumentation and debate. USA: Wadsworth Cencage Learning.

Fusaro, M. (2009). Building vocabulary to improve reading. Usable knowledge, connecting research to practice. Retrieved August 3 , 2014 from http://www.gse.harvard.edu/news/uk/09/05/building-vocabulary-improve-reading.

Gass, S. \& Selinker, L. (2001). Second language acquisition, An introductory course. USA: Lawrence Erlbaum Associates, Publishers.

Ghazal, L. (2007). Learning vocabulary in EFL contexts through vocabulary learning strategies. Novitas-ROYAL 1(2) 84-91. ISSN: $1307-4733$.

Guba, E. G., \& Lincoln, Y. S. (1994). Competing paradigms in qualitative research. In N. K. Denzin \& Y. S. Lincoln (Eds.), 
Handbook of qualitative research. USA: Sage.

Goodwin, J. (2003). Students' perspectives on debate exercises in content area classes. Communication Education, 52 (2), 157-163. Retrieved on April 29, 2013 from www.goodwin.public.iastate.edu/pubs/goodwinstudents.pdf.

Gu, Y. (2003). Vocabulary learning in a second language: Person, task, context and strategies. Teaching English as a Second or Foreign Language 7 (2). Retrieved from http://www.tesl-ej.org/ej26/a4.html.Gu, Y. (2010). Learning strategies for vocabulary development. Reflections on English Language Teaching, 9 (2) 105-118. Retrieved from http://www.nus.edu.sg/celc/research/books/relt/vo19/no2/105to118_gu.pdf.

Guest, G., Namey, E. \& Mitchell, M. (2013). Collecting qualitative data: A field manual for applied research. California, USA: Sage Publications.

Hadley, A. O. (2000). Teaching language in contexts. USA: Cencage Publishing.

Hall, D. (2011). Debate innovative teaching to enhance critical thinking and communication skills in healthcare professionals. The Internet Journal of Allied Health Sciences and Practice. Retrieved on May, 9, 2013 from:

http://ijahsp.nova.edu/articles/Vol9Num3/pdf/Hall.pdf.

Harmer, J. (1993). The practice of English language teaching. Essex: Longman Group UK LimitedLimited.

Inoue, N. \& Nakano, M. (2004). The benefits and costs of participating in competitive debate activities: Differences between Japanese and American college students. Paper presented at Wake Forest University/International society for the study of argumentation, Venice argumentation conference, June 27-30.

Kennedy, R. (2009). The power of in-class debates. Active Learning in Higher Education, 10 (3), 225-236. Retrieved June 3, 2013 from alh.sagepub.com/content/10/3/225.full.pdf.

Krashen, S. (1987). Principles and practices in second language acquisition. New York: Prentice-Hall.

Krashen, S. (1993). The power of reading: Insights from the research. Englewood, Co.: Libraries Unlimited.

Krefting, L. (1991). Rigor in qualitative research: The assessment of trustworthiness. The American journal of occupational therapy. March 1991, Volume 45(3), pp. 214-222. Retrieved on February 1, 2013 from

http://portal.limkokwing.net/modulemat/rigor\%20in\%20qualitative\%20research\%20trustworthiness\%20test(1).pdf.

Kirkpatrick, A. (2010). English as a lingua franca in ASEAN: A multilingual model. Hong Kong: Hong Kong University Press.

Krueger, R.A. (2002). Designing and conducting focus group interviews. Retrieved March 16, 2013 from

http://www.eiu.edu/ ihec/Krueger-FocusGroupInterviews.pdf.

Maxwell, J.A. (2005). Qualitative research design: An interactive approach. USA: Sage Publications.

Merriam, S.B. (1998). Qualitative research and case study applications in Education. California, USA: Jossey-Bass, Inc. Publishers. Miles, M. B., Huberman, M. A. \& Saldaña, J. (2014). Qualitative data analysis: A methods sourcebook. USA: Sage.

Mizumoto, A. \& Takeuchi, O. (2008). Exploring the driving forces behind TOEIC scores: Focusing on vocabulary learning strategies, motivation, and study time. JACET Journal, 46, 17-32. Retrieved from http://kuir.jm.kansai-

u.ac.jp/dspace/bitstream/10112/7016/1/KU-1100-20080325-06.pdf.

Padgett, D. K. (2004). The Qualitative research experience. New York: Thomson.

Patton, M. (2002). A guide to using qualitative research methodology. Medecins Sans Frontiers. Retrieved February 14, 2014 from http://fieldresearch.msf.org/msf/bitstream/10144/84230/1/Qualitative\%20research\%20methodology.pdf.

Richards, J. and Rodgers, T. (2001). Approaches and methods in language teaching. UK: Cambridge University Press.

Richards, J. (2008). Moving beyond the plateau: From intermediate to advanced levels in language learning. USA: Cambridge University Press.

Rudestam, K. E., \& Newton, R. R. (2007). Surviving your dissertation. USA: Sage.

Ryan, J. (2009). The three fundamentals of effective leadership. Retrieved June 15, 2014 from

http://www.forbes.com/2009/04/29/vision-communication-judgment-leadership-managing-ccl.html.

Scott, S. (2008). Perceptions of Students' Learning Critical Thinking through Debate in a Technology Classroom: A Case Study.

Journal of Technology Studies, 34 (1), 39-44.

Schmidt, R. (1990). The role of consciousness in second language learning. Applied Linguistics 11, 129-158.

Schmidt, R. (2010). Attention, awareness, and individual differences in language learning. In W. M. Chan, S. Chi, K. N. Cin, J.

Istanto, M. Nagami, J. W. Sew, T. Suthiwan, \& I. Walker, Proceedings of CLaSIC 2010, Singapore, December 2-4 (pp. 721-737).

Singapore: National University of Singapore, Centre for Language Studies. Retrieved May, 1, 2014 from

http://nflrc.hawaii.edu/PDFs/SCHMIDT\%20Attention,\%20awareness, \%20and\%20individual\%20differences.pdf.

Snider, A. \& Schnurer, M. (2006). Many Sides: Debate Across the Curriculum. USA: IDEBATE Press.

Stake, R. (2005). Qualitative case studies. In Norman K. Denzin \& Yvonna S. Lincoln (Eds.), Qualitative research (3 ${ }^{\text {rd }}$ ed.). $433-466$.

Thousand Oaks, CA: Sage Publications.

Sternberg, R. J. (1987). Most vocabulary is learned from context. In M. G. McKeown \& M. E. Curtis (Eds.), The nature of vocabulary acquisition, 89-105. Hillsdale, NJ: Lawrence Erlbaum Associates.

Sun, A. S. (2008). Input processing in second language acquisition: Teachers College, Columbia University, Working Papers in

TESOL \& Applied Linguistics, 20088 (1), 1-10. Retrieved from http://journals.tc-

library.org/index.php/tesol/article/download/359/260.

Thorndike, E (1999). Education Psychology. New York: Routledge.

Tracy, S. J. (2013). Qualitative research methods.UK: Wiley-Blackwell.

Wilkins, D. (1987). Linguistics in language teaching. London: Edward Arnold.

Yang, C. H. \& Rusli, E. (2012). Using debate as a pedagogical tool in enhancing pre-service teachers' learning and critical thinking. Journal of International Education Research - Second Quarter 2012. The Clute Institute. Retrieved May 13, 2012 from

eric.ed.gov/?id=EJ982692. 